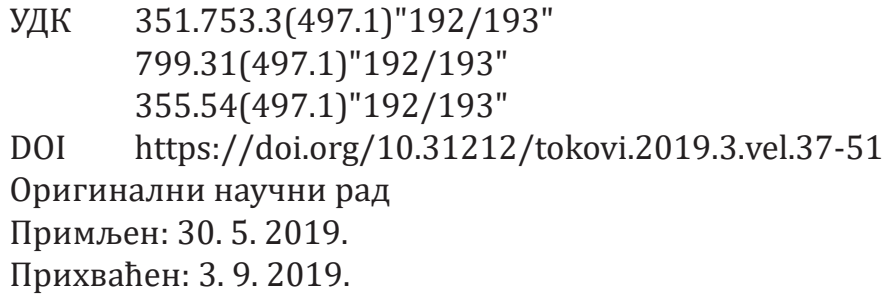

Dalibor VELOJIĆ

Institute for Serbian Culture, Priština, Leposavić

d.velojic@yahoo.com

\title{
The Role of the Army in the Development of Shooting Sports in the Kingdom of Serbs, Croats, and Slovenes/Yugoslavia*
}

\begin{abstract}
On the basis of records kept at the Archives of Yugoslavia, files in the ministry of physical education and sports, military archives, and other reference sources, this paper aims to shed light on the role of the army in the development of shooting sports in Yugoslavia between the two world wars. As a purely military sport, shooting relied on military organizations, with a significant number of officers and soldiers taking part in contests or in management of local shooting clubs. In addition to this, the law stipulated that military commands should exercise authority over these sporting activities.
\end{abstract}

Key words: Kingdom of Serbs, Croats, and Slovenes/Yugoslavia, Army, Shooting, The Ministry of the Army and the Navy, Sports

Shooting sports date back to the middle ages, when shooting contests with bow and arrow were held on a regular basis. With the invention of firearms, these contests were originally held using arquebuses, an early type of portable gun supported on a tripod or a forked rest, while shooting continued to develop as a separate discipline. In the 19th century, this group of sports appeared in the Olympic games. ${ }^{1}$ A shooting range

\footnotetext{
* $\quad$ The paper was written within the project Material and Spiritual Culture of Kosovo and Metojija (No 178028), approved and financed by the Ministry of Education, Science and Technological Development of the Republic of Serbia.

1 For more information see: Љубомир Ж. Петровић, Историја српског стрељаштва, (Београд: Институт за савремену историју, 2011), 23-24.
} 
was built in Belgrade, Serbia, in 1851, and the first shooting society was founded a few years later, in 1866. In the following decades shooting societies were formed in the towns of Niš, Valjevo, Kragujevac, Negotin, and Pirot. ${ }^{2}$ After the end of World War I, shooting societies in the Kingdom of Serbs, Croats, and Slovenes renewed their activity in 1924, when the Kingdom's Shooting Association was established.

Typical of shooting, albeit a bit more expressed in relation to other sports, was the close connection with the army. The president of the shooting society in Serbia was an officer (Milojko Lešjanin). ${ }^{3}$ Commissioned and non-commissioned officers took part in shooting contests on a large scale and often won the main prizes. This was supported by a general tendency to militarize physical culture in European countries between the two world wars, and Yugoslavia followed suit. ${ }^{4}$ Considering the massive scale of the first war, which engaged significant human potentials, the importance of sports and militarization of physical culture was evident in most countries. ${ }^{5}$ It is a fact that compulsory military service provided better knowledge of the army and brought it closer to civilians, but young people were not well-informed about the problems of defending the country, prior to their conscription. ${ }^{6}$ Bearing this in mind, the countries defeated in World War I started organizing their young people into sports combat or semi-military groups, which enabled them to increase their military efficiency within the limits established by the peace treaties, almost unnoticeably. ${ }^{7}$ In response, the protector countries of the Versailles Treaty, potentially endangered by this, also made an effort to organize their young people in a similar way. Countries such as the United States, France, Great Britain, Poland, Czechoslovakia, and the Soviet Union, went the furthest in these activities within the frames of their institutions and ministries of physical education and sports. ${ }^{8}$ The Kingdom of Yugoslavia followed these tendencies, considering that it was surrounded by revisionist countries such as Italy, Bulgaria, and Hungary. Fear of

\footnotetext{
$2 \quad$ Ibid., 24-54, 55-68.

3 Ibid., 37.

4 Mile Bjelajac, Vojska Kraljevine SHS/Jugoslavije 1922/1935, (Beograd: Institut za noviju istoriju Srbije), 1994, 225.

5 Далибор Велојић, Војска у Нишу 1918-1941, (Лепосавић: Институт за српску културу), 2014, 221.

6 Илија Панић, „Војска и опште образовање наше омладине“, Ратник XI-XII, (Београд), 1927, 87-95.

7 Nikola Žutić, Sokoli. Ideologija u fizičkoj kulturi Kraljevine Jugoslavije 1929-1941, (Beograd: Angrotrejd, 1991), 63-64.

8 Ibid., 64-65.
} 
neighboring countries proved justified in the mid-thirties, when it became clear that the system created at the Versailles Peace Conference was not sustainable. Therefore, physical education of young people demanded a special strategy by the state, as well as financial and expert assistance to organizations carrying out such education.

The Shooting Association was meant to spread the shooting movement in the Kingdom, to train young people in shooting skills and prepare them to defend the country if necessary. ${ }^{9}$ Under the authority of the Association there were shooting districts, and they enveloped all shooting societies on their territory. Another aspect typical of shooting was that the inner organizational structure matched the military territorial division. Namely, the shooting district territory matched the territory of the corresponding military district, and their seats were in command headquarters. ${ }^{10}$ Such a distribution contributed to an immediate functional cooperation of local military authorities with the authorities of the shooting districts and societies. Regular members of shooting societies were citizens of the Kingdom, over 18 years of age. Part-time members were soldiers doing military service as well as students not younger than 16 , who trained exclusively with practice weapons. ${ }^{11}$ The propositions of the ministry of the army and navy from 1936 to allow full membership to secondary school students, was rejected since it was not in accordance with the Law on Secondary Schools, which stated that students could be members of their own societies as well as the Red Cross, the Sokol Movement, and Youth Hostel Associations. ${ }^{12}$

Forming shooting associations became more frequent in the $1930 \mathrm{~s}$. Regulations for forming societies anticipated initiative by the citizens themselves, who elected the president and the board of the society at meetings. Society rules had to be in accordance with the rules of shooting societies, with slight additions allowed.

Attached to the application sent to the Association, there was ordinance, minutes from the founding assembly, as well as clear definitions of territorial and military affiliation. ${ }^{13}$ Deliverance of the application with

9 „Нацрт уредбе стрељачког савеза Краљевине СХС“, Стрељачки гласник, бр. 1-2, 1927, 2.

10 Archives of Yugoslavia (Arhiv Jugoslavije - AJ), Fond 71, Ministarstvo fizičkog vaspitanja naroda, f. 1, Predlog zakona o streljačkim dužinama.

11 Ibid.

12 Ibid., Prepis odgovora Ministarstva prosvete Ministarstvu vojske i mornarice s. n. br. 12205 od 21. aprila 1936.

13 Ibid., Uputstvo za osnivanje, obnavljanje i rad streljačkih družina izdato od streljačkog saveza Kraljevine Jugoslavije br. 1317 od 1. januara 1933. 
the ordinance had no formal character whatsoever, but it meant rigorous control by the Association, the ministry, as well as the local authorities. A typical example was the shooting society from Daruvar, whose application was rejected due to bad ordinance and inconsistence with the Law on Societies. ${ }^{14}$

Due to increased interest of the state in promoting this sport, the number of shooting societies in Kingdom of Yugoslavia rose rapidly. In 1926, there were only 10 active societies out of 100 registered, while 10 years later the number rose to $1,600 .{ }^{15}$ According to data from 1935 , shooting societies in Yugoslavia numbered about 80,000 members. ${ }^{16}$ The number of societies, in evidence of the ministry of the army and the navy from 1937 was 1,804, whereas the following year, 82 new societies had been formed and 142 discontinued. The condition in military districts was as follows: ${ }^{17}$

\begin{tabular}{|l|c|c|c|c|}
\hline Military district & $\begin{array}{c}\text { Condition at the } \\
\text { end of 1937 }\end{array}$ & $\begin{array}{c}\text { Founded } \\
\text { in 1938 }\end{array}$ & $\begin{array}{c}\text { Discontinued } \\
\text { in 1938 }\end{array}$ & Total \\
\hline Valjevo & 23 & 3 & - & 26 \\
\hline Šabac & 7 & 2 & - & 9 \\
\hline Sr. Mitrovica & 28 & - & 2 & 26 \\
\hline Ruma & 22 & - & - & 22 \\
\hline Pančevo & 4 & - & - & 4 \\
\hline Beograd & 20 & 2 & - & 22 \\
\hline Sombor & 15 & - & - & 15 \\
\hline Petrovgrad & 6 & - & 1 & 5 \\
\hline St. Bečej & 14 & - & 4 & 10 \\
\hline Sarajevo & 18 & - & 1 & 17 \\
\hline Travnik & 4 & - & - & 4 \\
\hline Tuzla & 9 & 1 & 1 & 9 \\
\hline Knin & 16 & - & - & 16 \\
\hline Sinj & 82 & - & - & 82 \\
\hline Mostar & 21 & - & - & 21 \\
\hline Trebinje & 7 & - & - & 7 \\
\hline
\end{tabular}

14 AJ, 71-38-123, Odobrenje pravila streljačke družine u Daruvaru.

15 Bjelajac, Vojska Kraljevine SHS, 257; Žutić, Sokoli, 75.

16 AJ, 71-38-124, Ministarstvo fizičkog vaspitanja naroda br. 8373 od 21. novembra 1935.

17 Table made on: AJ, 71-1, Brojni pregled streljačkih družina 1937/38. po vojnim okruzima. 


\begin{tabular}{|c|c|c|c|c|}
\hline Cetinje & 70 & - & - & 70 \\
\hline Pljevlja & 36 & 6 & - & 42 \\
\hline Petrinja & 9 & - & 2 & 7 \\
\hline Banja Luka & 14 & - & - & 14 \\
\hline Otočac & 15 & - & 7 & 8 \\
\hline Velež & 44 & - & - & 44 \\
\hline Kumanovo & 8 & - & 2 & 6 \\
\hline Štip & 33 & - & 1 & 32 \\
\hline K. Mitrovica & 15 & 2 & - & 17 \\
\hline Prizren & 27 & 9 & - & 6 \\
\hline Priština & 38 & 3 & 4 & 37 \\
\hline Kičevo & 38 & 1 & - & 39 \\
\hline Skoplje & 14 & 1 & - & 15 \\
\hline Bitolj & 19 & 4 & - & 23 \\
\hline Zagreb & 23 & - & 16 & 7 \\
\hline Varaždin & 73 & - & 23 & 50 \\
\hline Karlovac & 86 & - & 48 & 38 \\
\hline Osijek & 36 & 3 & - & 39 \\
\hline Bjelovar & 26 & - & 6 & 14 \\
\hline Požega & 31 & 8 & 4 & 35 \\
\hline Celje & 55 & - & 6 & 49 \\
\hline Ljubljana & 79 & - & 1 & 78 \\
\hline Maribor & 46 & - & - & 46 \\
\hline Vranje & 60 & 1 & 4 & 57 \\
\hline Pirot & 38 & 3 & - & 41 \\
\hline Prokuplje & 60 & 6 & 7 & 59 \\
\hline Užice & 86 & 5 & - & 91 \\
\hline Kragujevac & 169 & 10 & 1 & 178 \\
\hline Kruševac & 71 & 3 & - & 74 \\
\hline Požarevac & 85 & 1 & - & 86 \\
\hline Knjaževac & 50 & 5 & - & 55 \\
\hline Negotin & 60 & 3 & 1 & 62 \\
\hline Total & 1,804 & 82 & 142 & 1,744 \\
\hline
\end{tabular}

Shooting societies had the best cooperation with the Sokol Movement, who had handling of firearms as part of their training. To this aim, shooting teams were formed within the Sokol societies, with the primary goal of preparing future soldiers, but also contestants for shooting contests. The problem faced by the Sokol societies was the lack of weapons 
for shooting practice. During the visit of the Belgrade Sokol Movement to a shooting society, the interest of those young people was evident, but it was impossible to provide adequate rifles for them. ${ }^{18}$ This problem prompted the defense minister to issue orders that standard procedure for giving weapons to shooting societies be applied to Sokol societies alike. Shooting clubs in the Sokol societies would receive rifles from warehouses of military districts or gendarmerie squads. Also, the newly formed shooting clubs were entitled to 2,000 bullets as assistance, while additional ammunition was provided at the same price as for registered shooting societies. ${ }^{19}$

Shooting societies were also tightly connected with hunting groups. However, hunting shooting in Yugoslavia did not accomplish good results, primarily due to a lack of financial funds. In November of 1938, inter-Balkan shooting contests were held in Sofia, where contestants from Bulgaria, Greece and Romania took part, with only one contestant from Yugoslavia, which was interpreted as an act of politeness only. ${ }^{20}$ One month earlier, the ministry of foreign affairs received a document from the Yugoslav Embassy in Sofia, describing a hunting exhibition in Bulgaria and pointing out that hunting contributed to Bulgaria's economy with about 300,000,000 leva per year. ${ }^{21}$ The following year, the Greek hunting association invited Yugoslav hunters to compete in shooting contests, but the reply was that there were no hunting-shooting contests in Yugoslavia yet, since funding had not been provided. ${ }^{22}$ However, certain hunting societies did make efforts to promote this sport. The association of the hunting clubs of Zeta Province asked the ministry of physical culture for financial aid to construct a modern shooting range. ${ }^{23}$ Hunting-shooting contests were planned on the territory of Primorje Province, and they asked money from the state. ${ }^{24}$

18 „Београдски соколи на стрелишту“, Стрељачки гласник, бр. 1-2, 1926, 7.

19 AJ, 71-38-126, Naređenje Ministarstva vojske i mornarice a. s. br. 21353 od 31. decembra 1937; Military Archives (Vojni arhiv - VA), P. 17, k. 217, f. 4, d. 4, Molba sokolske čete sreza Gacko br. 144. od 30. jula 1939.

20 AJ-71-38-122, Pismo Saveza lovačkih udruženja Ministarstvu fizičkog vaspitanja naroda od 15. novembra 1938.

21 Ibid., Poslanstvo u Sofiji Ministarstvu inostranih poslova br. 1176 od 12. oktobra 1938.

22 Ibid., Savez lovačkih udruženja Ministarstvu fizičkog vaspitanja naroda od 27. maja 1939.

23 Ibid., Molba Saveza lovačkih društava Zetske banovine Ministarstvu fizičkog vaspitanja naroda br. 154 od 22. juna 1939.

24 Ibid., Molba Saveza lovačkih društava Primorske banovine Ministarstvu fizičkog vaspitanja naroda br. 184/39 od 16. juna 1939. 
The army had an active role in supporting and financing various associations, above all sports associations, and very often acted as the main initiator. As for shooting, we have to bear in mind the purely military character of this sport, which emphasized close bonds between the shooting association and the ministry of the army and the navy, and at the local level, the links between shooting societies and army garrisons and district command headquarters. The military authorities, above all, supported the shooting societies financially. In practice, this meant providing weapons and ammunition, awarding prizes and enabling access to firing ranges.

Assistance to shooting societies was originally regulated in the Kingdom of Serbia by the Law on Assisting Shooting and Sokol Societies and Equestrian Clubs, the regulations of which were accepted by the new state. The law stated that the military minister was authorized to provide ammunition for the shooting societies for local shooting practice, from military warehouses, at $50 \%$ discount, while generally, shooting ammunition was given free of charge. Each local shooting society, received two rifles with 1,000 bullets each from the army upon its establishment. ${ }^{25}$ Commanders of the districts had to send reports on shooting societies directly to the artillery technical department of the ministry of the army and navy. Reports had to contain information about the number of rifles and ammunition given to particular societies, and how much ordnance remained in the military warehouses, in case they had to be sold or given to newly founded societies. ${ }^{26}$

As for shooting ranges, the situation differed from garrison to garrison. Providing the range for civil shooting came under the jurisdiction of the military authorities, but in certain towns the shooting societies bought plots of land so as to depend on the garrisons as little as possible. This was especially the case in smaller places that had no military barracks. However, the draft Law on Building Sports Centers anticipated the building of firing ranges ${ }^{27}$ Among the numerous requests for help in building firing ranges were those from Slovenska Konjica, Senj, Djakovo, Jablanac, and Užice, whose old range was built on a private estate... ${ }^{28}$ Bigger towns, like Kruševac for instance, had their shooting ranges where they also provid-

25 „Закон о потпомагању стрељачких и гимнастичких дружина и пет кола јахача“, Службени војни лист Краљевине Србије (СВЛ) , 22. 4. 1892, 434-436 ; „Наређење о потпомагању стрељачких дружина“, СВЛ, 19.1.1928, 79-80; VA, P. 17, k. 217, f. 1, d. 8.

26 СВЛ, 18. 10.1930, 2094-2095.

27 AJ, 71-1, Projekat Zakona o podizanju vežbaonica.

28 AJ, 71-38-125, Molbe streljačkih družina za podizanje strelišta. 
ed premises for the range warden. ${ }^{29}$ In Belgrade, there was a range near Careva Ćuprija, but a garrison range in Jajinci was also used. ${ }^{30}$ In Sarajevo, land was provided by lease for 15 years, where they built a range with 15 targets. ${ }^{31}$ Zagreb had a military shooting range at Maksimir Park. Although inadequate, it also served civilians who had their practice time on Saturdays and Sundays. ${ }^{32}$ Niš had a range in Apelovac for civilian needs. ${ }^{33}$ This range, originally military, near the brewery, was used for civil competition as early as the beginning of the 20th century; 200 meters long and 20 meters wide, it was adequate for training and contests. It also had trenches and ramparts, and a roof was constructed in case of rain. ${ }^{34}$ The military range was situated in Gabrovac, but it had poor ramparts, so the army was given part of the land on Apelovac. ${ }^{35}$

In addition to financial assistance, the participation of officers in the activities of shooting societies was also of great importance. In the society itself, the vice president always had the rank of a general, as was the case with the governing board. According to data from 1939, there were five generals, one colonel and one lieutenant-colonel in the governing board of the Association of Shooting Societies. ${ }^{36}$ As suggested by a state defense inspection, the Association was advised to involve active officers in the activity of shooting districts as trainers or supervisors, in order to improve the quality of the sport. ${ }^{37}$ Examples of such active participation of officers to improve the sport are numerous. In Sarajevo, General Grgur Ristić managed to get the aforementioned land to build a shooting range. ${ }^{38}$ In Zagreb, General Steva Radovanović, the district commander, was elect-

29 Ibid.

30 VA, P. 17, k. 91, f. 1, d. 5, Naređenje inžinjerijsko-tehničkog odeljenja Ministarstva vojske i mornarice br. 13811 od 13. avgusta 1935.

31 „Извештај из Сарајева“, Стрељачки гласник, бр. 5, 1928, 3.

32 First and third week of the month, the firing range was booked for 35th infrantry regiment, whereas the second and the fourth week were left for other garrison units. 6th regiment of horse practiced on Mondays, 4th air regiment on Tuesdays, the 30th artillery regiment on Wednesdays, while Friday was reserved for 2nd anti-aircraft regiment. VA, P. 17, k. 913, f. 4, d. 43, Raspored gađanja na strelištu Maksimir.

33 Велојић, Војска у Нишу, 35.

34 Б. Тикић, „Апеловац, стрелиште“, Енциклопедија Нища. Спорт, (Ниш, 2015), 414.

35 VA, P. 17, k. 255, f. 3, d. 18, 1, Referat načelnika inžinjerijsko-tehničkog odeljenja Ministarstvu vojske i mornarice br. 14390 od 25. avgusta 1933; Ibid., k. 256, f. 1, d. 30, Rešenje Ministarstva finansija br. 44040 od 15. novembra 1933.

36 VA, P. 17, k. 206, f. 5, d. 17, Streljački savez Kraljevine Jugoslavije br. 1420 od 9. juna 1939.

37 AJ, 71-38-124, Inspekcija zemaljske odbrane Savezu streljačkih družina iz 1937.

38 „Извештај из Сарајева“, Стрељачки гласник, бр. 5, 1928, 3. 
ed as vice president of the society. ${ }^{39}$ In Kragujevac, while presiding over the society, general Vladimir Skubic assisted in building the range, providing ammunition, and forming around 40 new societies in Šumadija. ${ }^{40}$ While general Popović presided over the Ljubljana District, shooting festivities were held in 1932, judged by King Aleksandar himself. ${ }^{41}$ The military district in Cetinje, which was one of the poorer ones, formed 28 societies with 1,292 members, which was mainly contributed by the commander, Colonel Živorad Lazarević, awarded by the defense minister. ${ }^{42}$ The society in Niš cited garrison generals, led by General Sreten Todorović, commander deputy of the Morava District division, as regularly winning first prizes in shooting contests..$^{43}$ In parts of the state where it was necessary to spread the national idea through sport (particularly Kosovo and Macedonia), it was important to involve military officers. For instance, in Veles, Macedonia, the society president was Colonel Dragoljub Ćirić, and it was similar in Kratovo, Kriva Palanka, Priština, and Gnjilane. ${ }^{44}$ In Štip, the district commander, General Boško Toskić, reorganized the society into one of the biggest in the country. ${ }^{45}$ This society was rewarded with a rifle and a gun by the ministry of the army for their achieved results. ${ }^{46} \mathrm{In}$ Bitolj, the officers also contributed to repairing the range and providing more intensive practice. ${ }^{47}$

Shooting societies were monitored by district commands. The suggested measures of the ministry of the army on supervising the societies by officers meant not only training, but also control of their overall activity, particularly the acceptance of new members and preventing any possible negative activity. Poor performance of societies affected priority in financing, or supply of weapons, and this often led to their discontinuation. Delivery of weapons and ammunition was terminated in Vučitrn, due to fear of misuse. ${ }^{48}$ The same reasons made command of military district

39 „Стрељачки покрет“, Стрељачки гласник, бр. 3-4, 1927, 5.

40 „Стрељачки покрет у Шумадији“, Стрељачки гласник, бр. 1-2, 1927, 2.

41 „Стрељачке свечаности у Љубљани“, Стрељачки глсник, бр. 5, 1932, 5.

42 „Једна заслужена похвала“, Стрељачки глсник, бр. 4, 1932, 5.

43 „Наградно гађање“, Нишке новине, бр. 27, 1932, 4.

44 „Стрељачки покрет“, Стрељачки гласник, бр. 3-4, 1927, 5.

45 AJ, 71-38-125, Komanda mesta u Štipu ministru fizičkog vaspitanja br. 424 od 24. marta 1936.

46 VA, P. 17, k. 218, f. 2, d. 25, Naređenje Ministarstva vojske i mornarice artiljerijsko-tehničkog odelenja pov. as. br. 18152 od 12. avgusta 1940.

47 AJ, 71-38-125.

48 AJ, 71-38-126, Zemaljska inspekcija Ministarstva vojske i mornarice br. 2953 od 31. oktobra 1935. 
in Pljevlja stop giving weapons to the society in Sokolac. ${ }^{49}$ Rifles were not given to the shooting society in Podgora, because of political tension. ${ }^{50}$ After the breakout of war in Europe and the neighboring countries gravitating toward Germany, precautionary measures were increased, particularly in the border areas. The shooting society of the village of Halovo near Zaječar was discontinued in 1940, and their weapons were confiscated, as they were close to the Bulgarian border and the villagers fled to Bulgaria. ${ }^{51}$ That same year, an order was issued to seize the weapons from all Sokol societies on the territory of Slovenia and Croatia, while in other parts it was forbidden to issue new ones. ${ }^{52}$

A dilemma, for the ministry of the army and the navy in particular, was control over the activity of the Association and the local societies alike. The manual on forming societies stated that the minister of the army and the navy could exercise control over the societies, through their representatives or association governments. ${ }^{53}$ The draft law clearly defined authorities and delimited the influence of the army and civilian organizations. Generally speaking, it predicted that the ministry of the army and the navy and the ministry of physical education control the work of the association and its assembly meetings together. The minister of the army and navy supervised the handling and maintenance of weapons, as well as the proper use and expenditure of ammunition. The association was under obligation to submit annual activity reports to the ministers. The minister of physical education was authorized:

1. to make an assessment of necessary funding from the budget as assistance to the association;

2. to present awards to the best shooters at shooting contests from approved budget subsidies;

3. to enable sending best shooting teams to international contests;

49 Ibid., Ministarstvo vojske i mornarice Ministarstvu unutrašnjih poslova pov. br. 3852 od 31. decembra 1936.

50 Ibid., Ministarstvo fizičkog vaspitanja naroda Savezu streljačkih družina pov. br. 961 od 10. novembra 1937.

51 VA, P. 17, k. 218, f. 2, d. 18. Ministarstvo vojske i mornarice artiljerijsko-tehničko odelenje pov. as. br. 18907 od 29. jula 1940.

52 Ibid., f. 3, d. 24, Naređenje Ministarstva vojske i mornarice artiljerijsko-tehničkog odelenja pov. as. br. 30829 od 10. decembra 1940.

53 AJ, 71-1, Uputstvo o osnivanju družina. 
4. to supply and concede necessary practice weapons to associations for training new members;

5. to undertake other measures necessary to assist the association in spreading and strengthening shooting sports.

6. Similarly, the authority of the military minister was as follows:

7. to assign to each newly-formed society in a village or poor town two rifles and 2,000 bullets, free of charge, as well as government assistance and basis for future functioning;

8. to issue each to society upon its formation, from three to 10 rifles each, with 1,000 bullets, at a quarter of retail value;

9. to issue to all societies ammunition at a quarter of the retail value according to a regular supply approved by the association;

10. to approve subsequent weapon supplies (additional three rifles) to societies that show improvement;

11. to assign necessary ammunition to the association for conducting contest shooting free of charge;

12. to provide the association with free ammunition for preparing the best shooters to compete at international contests;

13. to present annual awards to the best shooters;

14. to anticipate necessary annual budget funds as regular assistance to the association;

15. to create an annex to the Law on the Organization of the Army and the Navy, which would stipulate benefits to members of shooting societies concerning shorter military service;

16. to provide free printing of Streljački glasnik (Shooting Gazette) in the printing house of the ministry of the army;

17. to approve the use of military ranges for practice and contest shooting. ${ }^{54}$

In addition to a delimitation of authority, there also used to be disputes between the two ministries in the ensuing years. The military ministry laid claim to the shooting activities, considering their military character and contribution of the army to improving the sport. In 1926, two years after founding the association of the shooting societies, the paper Streljački glasnik clearly stated the wish of the ministry of the army and the navy to take stronger control and legalize the further development of this sport. The role of the military minister was clearly emphasized and his

54 Ibid. 
endeavor to overcome: "the numerous difficulties, which have until recently hindered the development of the shooting movement in the Kingdom, to reach the position it used to keep before the Great War." ${ }^{25}$ The minister ordered that commanders help in the founding and activity of shooting societies with all the means at their disposal. In addition to this, the main initiators of founding societies were to be officers, and a proposition was made that members should have shorter military service, and be dismissed from military exercises. ${ }^{56}$ However, there is no indication that the ministry of the army and navy wanted to adopt this sport in any way. From these and subsequent orders, we can see that there was a desire for a simpler control of state authorities concerning the supply of weapons and ammunition, as well as in organizing exercise and contests. In connection with a new draft law on shooting organizations in 1937, the military minister wrote to the minister of physical education that it was of primary concern to regulate the jurisdiction over the shooting societies and that considering their essential military character they needed to remain under the control of the ministry of the army and the navy. As a reason for this he claimed that shooting could not be categorized as a sport, but more precisely, as a branch of military shooting skill, and therefore it was a kind of semi-military organization. In addition, it was stated that shooting societies were mainly led by officers. Therefore, according to the military minister, it was impossible for these societies to be exclusively under the ministry of people's physical education, if the ministry of the army and the navy had the main concern about funds and supply of goods. He deemed that duality of authority as harmful and could cause a dispute, which would slow down the progress of shooting and its management, especially: "with the present political circumstances being unfavorable for the development of such organizations." The explanation at the end of the letter stated: "The ministry of people's physical education is burdened with multiple chivalry-sports organizations, so numerous shooting clubs of purely military character would make the main function of The ministry of people's physical education harder, should they remain a part of it.

Ever since the founding of the ministry of people's physical education, the shooting societies have shown a strong tendency to be a constituent part of the ministry of the army and the navy, and besides, it has been noticed that shooting societies have had a damaging effect on cur-

55 „Војска и стрељачки покрет“, Стрељачки гласник, бр. 1-2, 1926, 2.

56 Ibid. 
rent unfavorable political circumstances to the extent that some of them have interrupted their activities in certain areas of the state.

If shooting remains under the exclusive supervision of the ministry of the army and the navy, as an institution beyond politics, there is hope that the damaging influence of certain negative politics on shooting organizations would be smaller, which would probably keep shooting sports alive. Owing to the fact that shooting was earlier exclusively supervised by the army, it is considered a purely military organization and as such has been very useful for the interests of the country's defense." ${ }^{57}$

The reply to the minister of the army was given in the form of a new draft law, which stated the aforementioned duties of certain ministries over the supply and control of shooting societies. "The minister of physical education manages shooting societies in accordance with the ministry of the army and the navy, in cooperation with the authorized ministries for school youth and the authorized government and self-government bodies for non-school youth, as well as with chivalry-sports organizations practicing shooting. Explanation: the joint work of the ministry of physical education and the ministry of the army and the navy is necessary because the goal of the total obligatory physical education of the youth is to prepare them to defend the country; therefore it is of major interest for the ministry of the army and the navy." ${ }^{58}$

Despite the military character of shooting, like any other sport involving young people and the organization of contests, it needed the control of the ministry of physical education. In addition, school youth and other organizations, such as the Soko Movement of the Kingdom of Yugoslavia and the Association of Hunting Clubs were closely connected with shooting. On the other hand, the role of the army in the development of shooting could not be limited to material security only, but had to include far greater authority. In the mentioned letter of the military minister, unfavorable political circumstances were mentioned, which alluded to the development of separatist movements in the country. We do not have any data whatsoever to point out that this sport would have been completely discontinued in the separatist areas if controlled exclusively by the army, but reflecting the circumstances in the country at the end of the thirties, dualist authority would present, among other things, a more flexible solution for the survival of shooting societies.

57 AJ, 71-1, Ministarstvo vojske i mornarice Ministarstvu fizičkog vaspitanja naroda pov. br. 5334 od 27. decembra 1937.

58 Ibid., Projekat zakonske odredbe o dvojnoj nadležnosti nad streljačkim družinama. 


\section{Summary}

The establishment of shooting societies and organizations in the Kingdom of Yugoslavia, bearing in mind its military character, meant the active involvement of the ministry of the army and the navy. This involvement included supplying and selling weapons and ammunition to shooting societies, but also the participation of military officers in shooting practice and contests. Military garrisons provided significant assistance to shooting societies by providing shooting ranges, which made practice far easier. The involvement of military personnel, especially district commanders, improved the functioning of the societies to a large extent, particularly in the border areas. The Army shared authority over this sport with the ministry of physical education and sports, as regulated by the law. The attempt of the military minister to exercise absolute control for the sake of easier functioning failed, since this sport entailed cooperation with various civilian societies and organizations, for which other ministries were authorized.

\section{Sources and Literature}

- $\quad$ Arhiv Jugoslavije. Fond 71, Ministarstvo fizičkog vaspitanja.

- Vojni arhiv. Popisnik 17, Fond Vojske Kraljevine Jugoslavije.

- Bjelajac, Mile. Vojska Kraljevine SHS/Jugoslavije 1922-1935. Beograd: Institut za noviju istoriju Srbije, 1994.

- Velojić, Dalibor. Vojska u Nišu 1918-1941. Leposavić: Institut za srpsku kulturu, 2014. (cyrillic)

- Enciklopedija Niša. Sport. Niš, 2015. (cyrillic)

- Z Žutić, Nikola. Sokoli. Ideologija u fizičkoj kulturi Kraljevine 1929-1941. Beograd: Angrotrejd, 1991.

- Panić, Ilija. „Vojska i opšte obrazovanje naše školske omladine“. Ratnik XIXII, (Beograd), 1927, 87-95. (cyrillic)

- Petrović, Ljubomir. Istorija srpskog streljaštva. Beograd: Institut za savremenu istoriju, 2011. (cyrillic)

- $\quad$ Niške novine

- Službeni vojni list Kraljevine Srbije

- Službeni vojni list Kraljevine SHS/Jugoslavije

- $\quad$ Streljačkiglasnik 


\title{
Резиме
}

Далибор Велојић

\section{Улога војске у развоју стрељачког спорта у Краљевини СХС/Југославији}

\begin{abstract}
Апстракт: На основу грађе похрањене у Архиву Југославије, у фонду Министарства физичког васпитања народа, Војном архиву, као и на основу литературе, рад приказује улогу војске у развоју стрељаштва у Југославији у периоду између два светска рата. Као чисто војнички спорт, стрељаштво је свој ослонац налазило у војној организацији и ангажовало велики број официра и војника на такмичењима или у управама локалних клубова. Поред тога, војни врх је и законским регулативама озваничио надлежност над овим спортом.
\end{abstract}

Кључне речи: Краљевина СХС/Југославија, војска, стрељаштво, Министарство војске и морнарице, спорт

Оснивање дружина и организација стрељачког спорта у Краљевини СХC/Југославији, с обзиром на његов војнички карактер, било је везано за активно ангажовање Министарства војске и морнарице, што је подразумевало набавку и поклањање, односно продају оружја и муниције стрељачким дружинама, као и учешће официра у обуци и на такмичењима. Значајну помоћ гарнизони су стрељачким друштвима пружали око обезбеђивања стрелишта, а то је веома олакшавало вежбе. Ангажовање појединаца из војске, нарочито команданата места, унапредило је доста рад дружина, посебно у пограничним крајевима. Надзор над овим спортом војска је делила са надлежним Министарством физичког васпитања народа, и то је било регулисано законским актима. Покушај министра војног да спроведе апсолутну контролу ради лакшег функционисања није уродио плодом пошто је овај спорт подразумевао сарадњу са различитим цивилним друштвима и организацијама за које су била надлежна остала министарства. 